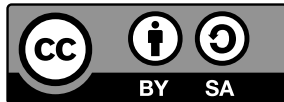

\title{
IMPLODING THE RACIALIZED AND PATRIARCHAL BEAUTY MYTH THROUGH THE CRITICAL LENS OF TONI MORRISON'S THE BLUEST EYE
}

Published in the aftermath of the American civil rights movement in 1970, The Bluest Eye investigates the premises of whiteness as a social category and draws attention to the perfidious ways in which constructs of racialized (and gendered) otherness are reinforced and sustained through the Western ideology of beauty. Told from the point of view of an informed narrator, an African-American girl Claudia McTeer, it recounts the story of another African-American girl, Pecola Breedlove, who yearns for blue eyes. She comes to believe that blue eyes would make her visible and beautiful in the eyes of others, and therefore accepted and loved. Pecola's desire for blue eyes or a whitened self is based on racialized standards of normative (feminine) beauty that saturate public and private space. These normative representations stare (down) at her and the rest of African-American community from literally every ad and hoarding, from cinema screens and magazine covers; they permeate school primers and toy designs such as dolls, and are found imprinted on everyday consumer products including milk cups and candy wrappings. Pecola's yearning for blue eyes or for being white signifies a displacement and erasure of her self, which inevitably leads to her descent into madness. As the title suggests, the yearning for the bluest "eye" is a yearning for the bluest self or whitest "I". This yearning for a racially imposed version of self, which is based on self-depreciation and disavowal, also turns the person thus affected into another manifestation of the "bluest" I: that is, the saddest or the bluest self, marked by a completely self-alienated and destroyed inner I, and a dysfunctional and politically passivized outer I.

In the afterword to the 1993 edition, Morrison explains that The Bluest Eye is based on a real life experience when, just upon starting primary school, an African-American classmate of hers confided in her that what she desired most was a pair of blue rather than brown eyes. Horrified by this demonstration of internalized "racial self-loathing", Morrison as an adult person decades later was "still wondering how one learns that" (1994: 210). The novel, as Morrison goes on to explain, was written to "peck away at the gaze that condemned" the girl and her community and "against the damaging internalization of assumptions of immutable inferiority originating in [this] outside gaze" (1994: 210). She wrote her first novel to expose the ideology behind the beauty myth and to annihilate the white gaze that declared the girl like 
generations of African-Americans before and after her "wanting" or deficient and therefore "a [] small weight on the beauty scale" (1994: 210). The novel exposes racialized norms of beauty as one of the governing mechanisms of white supremacy, dissecting and rejecting them while alerting its readership to the psychologically devastating consequences that a constant reproduction and reinforcement of racialized beauty standards has upon the minds of those subjected to this kind of "education" (Morrison 1994: 122) about their own selfworth. In the process of doing so, the novel does much more than just expose the gripping power of racist ideology, of which the beauty industry along with Hollywood cinematic gaze is its supportive subset. It also brings to the surface and deconstructs "scientific racial theory and $[\ldots]$ the hegemonic linguistic codes that give expression to such [constructions and] objectifications of race" (Baillie 2003: 21). The novel is, to adopt Baillie's expression, also "a literary political project" (2003: 25) in another sense. It brings to critical attention not only racialized but also gendered constructs of beauty, which mainstream literary criticism usually omits or only superficially addresses when referring to Morrison's first novel. This contribution seeks to rectify these omissions. By showing the beauty myth to be socially constructed and damaging, The Bluest Eye directly addresses not only racialized but also gendered constructs of beauty with the latter leading to the construction and implantation of a particular kind of insufficiency and consequently "woundability lodged in all girls" (Morrison 1994: 210). It demonstrates that the two seemingly separable categories of gender and race are structurally intertwined, hence also the novel's focus exclusively on girl protagonists. In addition, as this contribution also argues, the novel has a new and far-reaching pedagogical and political resonance for students of English literature today. A significant portion of the research presented in this article thus also brings to the fore the results of a pedagogical practice pursued on my part in the seminar on feminist literary studies. This is the kind of practice that seeks to combine the findings of feminist analysis of patriarchal beauty myth and postcolonial theories of race into a single unit of analysis, which in turn, as this contribution demonstrates, is also conducive to a highly informed reading of The Bluest Eye on the students' part. Such an integrated approach helps students to critically assess and resist contemporary and expanding beauty culture of capitalist patriarchy premised upon the sexualisation and objectification of women, and to recognize and deal with the ways in which the discourse of Western racial superiority continues to be evoked and naturalized in the context of neo-colonial globalization, its corporate multiculturalism and attendant globalized beauty industry.

\section{GENDERED AND RACIALIZED BEAUTY REGIMES: FORMS OF SOCIAL CONTROL AND DOMINATION}

The Bluest Eye presents a critically insightful entry point for readers in general and for students of English literature in particular to reflect on the issue of capitalist patriarchy and racism 
on a level that requires complex thinking informed by a historically contextual and socially engaged approach to literature. One of the primary concerns in the novel is the received notion of beauty and its internalization, which Morrison shows to be constructed on multiple and interlocked levels. Whether beauty is gendered or racialized, Western beauty standards rest on the objectification and disempowerment of the people they are targeted at. Western beauty regimes operate through the enforcement of impossible and carefully calculated ideals, which in turn construct the appearance and bodies of those they are targeted at as lacking and insufficient (Bordo 1993). In this sense, they breed not only unease with one's body and appearance in general but also insecurity and dissatisfaction with oneself. Beauty regimes function as disciplinary practices that help to position individuals and groups of people thus targeted as lesser. By keeping one's focus on preoccupation with one's appearances and bodies that are always constructed as inadequate and faulty (and in need of constant makeover or repair), beauty standards which are impossible to meet serve as a tool of control and depolitization. By keeping people fixated on their bodies and their ever more vulnerable (and superficially reconstructed) inner self, they not only drain their (already meagre) financial resources but also channel their energy away from relevant social issues affecting their lives and from a much-needed political engagement. Or as Bordo puts it, Western beauty ideals lead to pathologies and function as modes of producing docile subjects of late capitalist societies also in the sense that they "render[...] them less socially oriented and more centripetally focused on [continually failed projects of] self-modification" (1989: 14).

\subsection{Gendered beauty norms as a way of feminizing and controlling women}

Morrison captures the devastating effects of Western beauty ideology through the character of Pecola's mother, Pauline. Sick and tired of her domestic confinement, she finally extricates herself from the house, but with no other public place else to go to except cinema she settles for the latter. Here, in the belly of the Hollywood industry and its cinematic representations of feminine beauty and whiteness, Pauline is subjected to what Morrison calls a life-time "education" (1994: 122):

"There in the dark ... along with the idea of romantic love, she was introduced to another - physical beauty. [...]Probably the most destructive ideas in the history of human thought. Both originated in envy, thrived in insecurity, and ended in disillusion. In equating physical beauty with virtue, she stripped her mind, bound it, and collected self-contempt by the heap."

The fact that Morrison sends the mother rather than the father to the cinema is not a coincidence. Nor is the fact that it is mostly female characters that populate her story, 
with men appearing in side roles, and that it is women as central characters that are subjected to similar education or indoctrination like Pecola's mother. As pointed out by a number of feminists and cultural theoreticians alike, in the capitalist and imperial West, "the discourse and practices of beauty are [first and foremost] integral both to the production and regulation of femininity, and to asymmetrical relations of power between [men and women] and among women" (Davis 2003: 54). In the West, beauty regimes are targeted at women and function as disciplinary practices, the point of which is to produce "a feminine body out of a female one" (Bartky 2003: 34). To be feminine is to be associated with passivity, weakness and intuition rather than agency, reason, strength and presence of mind (Lister 1997). These are projected characteristics on the basis of which women have been realigned with nature and chaos and men with culture and order (Ortner 1972). The reinforcement of this artificial and hierarchical binary has been crucial to the construction of women's secondary status in Western capitalist societies. It has served as an ideological tool, on the basis of which women's confinement to the private sphere - and along with it the privatization and individualization rather than socialization of social reproductive work such as child care - continues to be naturalized and justified. Beauty industry, with its focus on the prescription of appearances, has a direct role in upholding the constructs of femininity and in reinforcing the gendered disequilibrium, with women constructed and positioned as subordinate and submissive and men as dominant and powerful (Bartky 2003). This is fundamental to capitalist patriarchies that rest on modernized breadwinner models.

Reduced to mere bodies to be decorated and bodies to be looked at, women within this economy of meaning are reconfigured and turned into a superficial spectral presence, a shadow presence, whose recognition depends on the assessing gaze of somebody else. This results in the imposition of a dichotomy of passivity and activity, with passivity reserved for the one reduced to the status of an object to be looked at, and activity for the one who looks and thus defines. Consequently, as put by John Berger (1998: 98), in this economy of meaning

men act and women appear. Men look at women. Women watch themselves being looked at. This determines not only most relations between men and women but also the relation of women to themselves. The surveyor of the woman in herself is male: the surveyed female. Thus she turns herself into an object - and most particularly an object of vision: a sight.

Beauty regimes passivize women, reducing them to a surface appearance without depth. Reduced to a mere body and to a status of "looked-at-ness" (Tate 2008: 24), women must learn to perceive and see themselves as "things looked at and acted upon" (Leeds Craig 2006: 162). Re-imagined and therefore positioned as being always and only body specific, women come to constitute the inner or outer margin of the social patriarchal 
order whose core comes to be perceived as supposedly naturally fused with and one with masculine reason and agency (Moi 1986).

In addition to passivizing and marginalizing women, beauty regimes act as disciplinary practices that control and restrict women. Rather than just merely describing and regulating women's appearances, beauty ideals and beauty practices function as reenforcers of women's secondary and subordinate (feminine) status. As pointed out by Bartky, within the (Eurocentric) economy of meaning, determined by the patriarchal gaze and internalized also by women in the beauty and fashion industry, 'an aesthetic of femininity mandates fragility' (2003: 34-35). This feminine beauty ideal in turn rests on the constant production of 'a body of a certain size and general configurations' and on 'a specific repertoire of gestures, postures and movements' (2003: 27). The aim is to produce and enforce the ideal of a tiny and frail, child-like female body, which in turn can be cast as an 'inferiorized body' (2003: 37). Accordingly, beauty regimes of Western capitalist patriarchies revolve around thinness verging on emaciation, infantilization (and animalization), and sexualisation of women. As explained by Bartky (2003: 35), a woman in contemporary Western patriarchy

must try to assume [...] the body of early adolescence, slight and unformed, a body lacking flesh or substance, a body in whose very contours the image of immaturity has been inscribed. The requirement that a woman maintain a smooth and hairless skin carries further the theme of inexperience, for an infantilized face must accompany her infantilized body. The face of the ideally feminine woman must never display the marks of character, wisdom, and experience that we so admire in men.

Facelifts, skin-peeling and botox help to temporary erase wrinkles and other sings associated with longevity and experience otherwise desired in men, while liposuction and dieting, anorexia and bulimia ensure that women, in subjecting themselves to the "tyranny of slenderness" (Bartky 2003:35), learn to approximate adolescently thin and unthreatening bodies. This helps to shrink the actual size of their adult bodies, making them appear not only small, narrow and harmless in taking up much less space in comparison to men, but also weak, permanently infantile and therefore subordinate. Teenage youthfulness or inexperience combined with sexually nubile but mentally not yet mature bodies contributes to the reinforcement of feminine and masculine binary. The beauty ideal of thinness for women has been accompanied by an increased sexualisation and objectification of women (Murnen and Seabrok 2012). Within the heteronormative patriarchal matrix, women are sexualized as passive bodies and trained to present themselves as an "object and prey for the man" (Bartky 2003: 34). Cast as "bodies designed to please and excite" others, they are expected to have no knowledge and demands of their own sexual pleasure (2003: 42). These are bodies that are always acted upon. Once positioned as sexualized bodies 
or sex objects, women are objectified and treated as less competent, less qualified and deserving than they really are (Murnen and Seabrok 2012: 441). While beauty industry touts women's heteronormative objectification and passive sexualisation as their ultimate power, it in fact serves as their ultimate disempowerment (McRobbie 2009). Women's emaciation, infantilization and sexualisation constitute the so-called "larger disciplines" of contemporary capitalist patriarchy and its attendant beauty industry that affect all women: they "construct a 'feminine body' out of a female one" regardless of its skin colour or class (Bartky 2003: 34). The target is all women for the aim is the same: this is the construction and reinforcement of a homogenously feminine body, that is, a 'subjected body ... a body on which inferior status has been inscribed" (Bartky 2003: 34). This is the kind of body that Western capitalist patriarchies constantly produce and reproduce as deficient and faulty, as inadequate and in need of change or makeover. The result is psychological insecurity and self-alienation on the part of women. Or, as put by Bartky: "to live in an inferiorized body is to be alienated from one's body, hence from oneself." (2002: 20).

The same mechanisms and effects are also at work in the production and maintenance of racialized, Eurocentric standards of beauty. In order to better explain the structural fusion between gendered and racialized norms of Western beauty regimes and the way this is captured in the novel, what follows first is a lengthier contextual analysis of racialized beauty norms and their modalities that the novel addresses either implicitly or explicitly. This integrated step-by-step approach, developed in my seminar on Anglo-American feminist literary studies and in my seminar on American literature at the Faculty of Arts in Ljubljana, has also turned out to be of crucial importance for MA students of English literature. It has helped them to develop critical thinking and a comprehensive understanding of the systemic nature and the workings of Western racialized and patriarchal beauty myth. This has resulted in some stunning observations and in-depth analyses on their part, which is why the remaining sections also include some of their written responses.

\subsection{Racialized constructs of beauty}

Racism and racialized constructs of beauty have their origin in the rise and consolidation of capitalist exploitative system in Europe and its imperial expansionism. Since its early inception in the $16^{\text {th }}$ century, this order has rested on the construction of inferiority and imposition of object status upon the peoples the West was to dispossess and exterminate, or preferably make use of and enslave, in order to subject them to its new mode of production and social organization. Race as a social construct was invented and maintained also by means of pseudoscience to artificially re-categorize people into those that qualified as human and were seen as endowed with reason, and those that would be stripped of humanity and constructed as the other, that is, as lacking in reason, and consequently, according to 
this construction, in culture and beauty (Camp 2015: 680). This othering proceeded on the basis of projecting imaginary insufficiencies and negative characteristics into selected groups of people under the pretext of their skin colour. Racism has "historically functioned to legitimize extreme oppression and inequality" (Wilson 1996: 125), that is, superexploitation of those constructed and denigrated as racialized others on the home turf of Western capitalist powers and in their colonial outposts. American slavery was just one of the epochs in the history of this system. That is why racism continues unabated today in the form of institutionalized racism which has mutated in content, having gone from biological to cultural racism (Burcar 2017). This is also something that the main narrator, Claudia McTeer, understands very well. Through her informed point of view, we come to share in her awareness and understanding of her peripheral status which is structurally maintained and further entrenched by the way her family and community continue to be defined as the ultimate and therefore super-exploited racialized other:

Being a minority in both caste and class, we moved about anyway on the hem of life, struggling to consolidate our weaknesses and hang on, or to creep singly up into the major folds of the garment. Our peripheral existence, however, was something we had learned to deal with. (Morrison 1994:19)

Racialized constructs of beauty have served as one of support mechanisms for assigning and inscribing imaginary racialized differences and deficiencies, and as one of the methods on the basis of which selected groups of people continue to be objectified and constructed as lesser and subordinate. In this sense, beauty binaries or "ideas about beauty and ugliness were and continue to be entangled with the invention and ongoing reinvention of race itself' (Camp 2015: 690). In the context of Western internal colonialism and external imperialism, the task of Eurocentric beauty ideology has been to uphold and naturalize the concept of white supremacy. For this purpose, beauty has been linked to whiteness and ugliness to those constructed as others on the basis of discursive operations known as binary operations. These have rested on the invention and division of races as though they existed in a hierarchical "opposition to one another": in this process, "black people and blackness were [thus] defined as barbaric, savage, heathen and ugly; white people and whiteness were defined as civilized, modern, Christian and beautiful" (Hunter 2005: 20). Consequently, also selected "features associated with whites, such as light skin, straight noses, and long, straight hair would take on meanings" that would link what are in fact neutral physical characteristics to psychological and cultural meanings, so that these selected features would also come to stand for one's personal character, that is, for "civility and rationality", and hence "beauty" (Hunter 2005: 9). In this sense, an early $20^{\text {th }}$-century pseudoscientist De Gobineau, whom Morrison also mentions in the novel, came up with a racist doctrine that the "white race was superior to all others in being", claiming further that "the human groups were unequal in beauty, [with] this 
inequality [being] rational, logical, permanent and indestructible" (qtd. in Baillie 2003: 27). Morrison confronts this doctrine head on by pointing to the way Americans of mixed ancestry end up as cogs in the machinery of whiteness, wrongly believing themselves to be closer to their white masters and above other members of their community while in fact being in the same boat with those they help to denigrate on behalf of their masters:

With the confidence born of a conviction of superiority, they performed well at schools. They were industrious, orderly, and energetic, hoping to prove beyond a doubt De Gobineau's hypothesis that "all civilizations derive from the white race, that none can exist without its help, and that a society is great and brilliant only so far as it preserves the blood of the noble group that created it." Thus, they were seldom overlooked by schoolmasters who recommended promising students for study abroad. (Morrison 1994: 68)

Morrison also goes on to show how this beauty doctrine has become an insidious platform of the Hollywood industry. It is through her exposure to cinematic constructs of whiteness and blackness that Pecola's mother acquires a lifetime education, after which she is "never able to look at a face and not assign it some category in the scale of absolute beauty" (1994: 122), the absolute beauty being whiteness or approximation of whiteness itself. At the same time, Morrison reminds us of the pernicious effects the doctrine of racialized beauty has on members of racialized groups, who by seeing themselves constructed as lacking and therefore as less beautiful or less human absorb this ideology in an environment that encourages their self-hatred rather than resistance. The result is a depoliticized and disunited body of people:

You looked at them and wondered why they were so ugly; you looked closely and could not find the source. Then you realized that it came from conviction [...]. It was as though some mysterious all-knowing master had given each one a cloak of ugliness to wear, and they had each accepted it without question. The master had said, "You are ugly people." They had looked about themselves and saw nothing to contradict the statement; saw, in fact, support for it leaning at them from every billboard, every movie, every glance. "Yes," they had said. "You are right." And they took the ugliness in their hands, threw it as a mantle over them, and went about the world with it. Dealing with it each according to his way. (1994: 39)

Morrison demonstrates that racialized beauty myth is all pervasive because it is institutionally maintained. It has to do with categorical devaluation of people: once labelled as deficient and lacking in beauty, which the West equates with humanity, the people thus targeted come to be homogenized as the ultimate other. 
Racialized beauty myth propped up by its attendant pseudoscientific discourses in the past and the "beauty-industrial complex" today functions as a tool of domination and social control (Robinson-Moore 2008: 67). Far from just having to do with the prescription and devaluation of appearances, racialized beauty norms play a direct role in the naturalization and maintenance of hierarchical social stratification. They help to "define who will qualify as a subject of recognition" (Tate 2008: 4), that is, who will and can qualify as human. Racialized beauty paradigms and practices therefore serve as a way of positioning people and as a way of symbolically reinforcing and maintaining inequality: they are used as powerful tools by means of which human presence is either bestowed or withheld. By rendering those defined as others invisible or less than nothing, they also help to implant a feeling of insufficiency, a feeling of human lack in the people thus defined. Their point is to make those targeted see themselves as less worthy, that is, to "see and experience themselves as Other" (hooks 1992: 3). In this sense, racialized beauty norms function as a means of social control. They "sediment [...] our structures of feeling" (Tate 2008: 4) and govern forms of perception and self-perception among those targeted as others as less deserving, as less human and therefore supposedly justifiably marginalized and exploited.

These complex processes, which have to do with the granting or denying of one's personhood, are best captured in what is one of the most memorable and evocative sections of The Bluest Eye. It pivots on Pecola's encounter with a white immigrant storeowner and the interaction or rather lack of it that ensues thereafter:

The gray head of Mr. Yacobowski looms up over the counter. He urges his eyes out of his thoughts to encounter her. [...] At some fixed point in time and space he senses that he need not waste the effort of a glance. He does not see her, because for him there is nothing to see. [...] She looks up at him and sees the vacuum where curiosity ought to lodge. And something more. The total absence of human recognition-the glazed separateness. [...]It has an edge; somewhere in the bottom lid is the distaste. She has seen it lurking in the eyes of all white people. So. The distaste must be for her, her blackness. [...] And it is the blackness that accounts for, that creates, the vacuum edged with distaste in white eyes. [...] Outside, Pecola feels the inexplicable shame ebb. [... and] well[] up again, its muddy rivulets seeping into her eyes.

This is also a pivotal section and a breaking point for the novel's readership and, even more so, for students of English literature. Equipped by now with the contextual understanding of patriarchal and racialized norms of beauty, students at this point are finally able to recognize and grasp the extent of the social power that Western constructs of beauty are invested with, and the ways they are deployed in order to exercise control upon those constructed and targeted as the other. This is one of the most powerful sections 
in the novel which allows students to gain a comprehensive insight into the operating mechanisms of Western beauty myth and to see how and why these normative constructs of beauty homogenize and "symbolically and functionally disempower" groups of people they are targeted at (Murnen and Seabrok 2012: 440).

This newly gained understanding is also clearly reflected in a representative selection of some of the observations presented by MA students in their 2016/2017 seminar on Anglo-American feminist literary studies, with the last two also bringing together the understanding of how gender and racialized constraints fall together into a single, unified frame:

\section{STUDENT A}

Morrison describes how someone can be completely dehumanized just because they do not conform to particular beauty standards. Pecola is black and because of that she is not just ugly in the eyes of Mr. Yacobowski, she is not even worth his glance. He does not want to look at her. It seems as if he is looking through her as if she were invisible. This invisibility is even worse than just hatred or disgust, because even if you are hated at least you are perceived as a person. But the "vacuum" in the man's eyes indicates that she is not worthy to be called a person, just because of the colour of her skin. [...] And all of this just because of a completely subjective, irrational perception of beauty that was artificially created by a society that is based on white supremacy.

\section{STUDENT B}

Mr. Yacobowski denies Pecola the status of a person based solely on Pecola's looks (more specifically, the fact that she is black). [...] Morrison clearly shows that this isn't an isolated event. It's not just Mr. Yacobowski who looks at Pecola that way; she has seen it "in the eyes of all white people". This type of domination is systemic, not individual. [...] When people strip Pecola of her personhood, they are immediately put into a dominant position, because even if they're an immigrant like Mr. Yacobowski, at least they're still a person.

\section{STUDENT C}

As soon as the storekeeper perceives Pecola's blackness, it triggers a detachment which categorizes her as the Other, someone who is marked by the color of her skin as not worth engaging on an equal basis. The narrator points out that his inability to perceive a black girl as a fellow human being stems not only from their diverse backgrounds, but specifically from the fact that his mind has been "honed on the doe-eyed Virgin Mary", a religiously-imbued, white ideal of beauty. 


\section{STUDENT D}

Morrison shows us that the shopkeeper is unable to see Pecola, not because he personally has anything against her as a person, but because she does not have the characteristics that, in his mind, constitute a person at all. His gaze is not filled with hatred against her, but a "total absence of human recognition". That is because he has been conditioned to recognize a person in relation to a certain standard, his mind is "honed on the doe-eyed Virgin Mary," who looks nothing like little black Pecola. Because she is so different from the ideal against which he evaluates women, he fails to register her as a subject at all. [... and] once the white gaze is internalized as a way of evaluating the world, it also becomes a way of evaluating one's self-worth. [Hence also Pecola's resurgent feeling of shame].

While Western prescribed standards of beauty are taken for granted and appear to be self-generating, they have their origin and continue to be "embedded in political economic systems of capital accumulation" (Taylor et. al. 2016: 128). They are primarily used as a means of social control and social positioning, with patriarchal and racialized paradigms functioning as two sides of the same coin. Capitalism itself rests on different forms and degrees of women's domestication and submission (or dependency) as well as on the othering and super-exploitation of those defined as racialized others. Racialized and gendered beauty norms constitute a complementary system of mutually reinforced discourses and practices. That is why, to adapt Naomi Wolf's observation, the beauty myth in the West is essentially not just about the prescription of appearances: "it is always actually prescribing behaviour" (1992: 14) and (self-)perception on the part of those that define and those that are defined. Those caught in the assessing and defining gaze of the definer are objectified and dehumanized, as well as manipulated with, precisely through the instalment of a feeling of inadequacy and self-worthlessness, which in turn leads to one's complete incapacitation.

\section{GENDERED AND RACIALIZED NORMS OF BEAUTY FUSED TOGETHER: RESISTING THE WHITE PATRIARCHAL GAZE}

In Western capitalist patriarchies, beauty norms first and foremost help to enforce and sustain the ideology of feminine inferiority and women's secondariness with the emphasis on the production of infantile, sexualized and emaciated bodies as being one with all female bodies (Davis 2003). Within capitalist patriarchies, beauty regimes in general are geared specifically towards women as they position them as passive objects of gaze, as a surface to be gazed at and acted upon. Consequently, in this economy of meanings it is also African-American women that bear the brunt of racialized beauty standards. 
Racialized beauty standards dehumanize and oppress those cast as racialized others in general, but because beauty norms are primarily gendered, racialized or "Eurocentric beauty paradigms" and practices are "more salient for black females than for black males" (Robinson-Moore 2008: 67). That is, in the patriarchal economy of gaze, racialized beauty norms are transposed onto women and act as a yardstick by means of which the femininity of African-American women, and by extension their acceptability and desirability, is itself measured and assessed in terms of their approximation to the ideals of whiteness, and thereby to white femininity by white and black men alike. Men, while appearing in the masculine role of definers or assessors, are exempted from these coercive beauty practices, which demand that women subject themselves to ongoing modifications in order to make their bodies and faces appear closer to prescribed standards of whiteness. Consequently, if in Western capitalist patriarchies the "feminine subject is [universally] defined as lack, as absence, then the black woman is doubly lacking, for she must simulate or feign her femininity as she dissimulates or conceals her blackness" (Grewal qtd. in Azouz, N. pg.). Racialized definitions of beauty rest on the promulgation of light skin and straight hair, and for African-American women to pass as beautiful or feminine enough, it has been a prerequisite for them not only to use bleaching creams to lighten or "prettify" their skin but to straighten their hair. While African-American men in the past would wear their hair unstraightened and trimmed close to their head or simply shaven to the skull today, African-American women to this day, in order to pass as acceptable or feminine, have been subjected to the regime of having their hair straightened by means of harmful chemicals (also known as relaxers) or through the painful application of hot metal combs and curling irons, which, while uncoiling and stretching the hair, also burn and damage it (Tate 2008: 43). Today, as pointed out by Tate (2008: 43, 44), "black hair stylization technologies", which have been always targeted specifically at African-American women, have expanded and serve either to "remove the frizz or hide it", thus "socializ[ing]" the hair of African-American women to make it appear closer to the white feminine ideal of long and flowing straight hair. It is for this reason that Pecola's mother is also looked down upon and devalued as a woman by her own peers. When she moves to Chicago, she "fe[els] uncomfortable with the few black women she met": all of them are "amused by her" because [at the time] "she did not [yet] straighten her hair" (Morrison 1994: 118).

Eurocentric constructs of normative beauty are targeted at all racialized people in general, but in the patriarchal system, based upon "specular-driven conceptions of beauty" (Munafo 1995: 6) that reduce women to the body and surface, they are applied to racialized women in particular. To pass as masculine, patriarchal white gaze is adopted and replicated by African-American men in relation to women, and internalized by AfricanAmerican women who, gendered and homogenized as feminine, are encumbered with the burdensome task to live up to the prescribed normative standards of beauty, defined as white feminine beauty. This conception of beauty is not only set up "in terms of the physical features that the people we consider white are more likely to have" (Taylor 2000: 
667), but is subjected to further internal selection and hierarchical re-organization. Or as put by Munafo, the conception of white feminine (physical) beauty "derives from a [further] distillation of "white' physical characteristics," so that they become subsumed under the label of "the Aryan ideal" (1995: 6), that is, an Anglo-Saxon or Nordic construct. A blueeyed and blonde-haired beauty icon is something that is very difficult to approximate already by a large number of women of European descent, and impossible to meet by African-American (and other racialized) women in general. Within this frame, gendered and racialized constructs of femininity coalesce. Eurocentric normative standards of feminine beauty "idealize fair skin, small noses and lips, and long flowing hair," and in turn define "black women's dark skin colour, facial features, and tightly curled, short hair as ugly" (Leeds Craig 2006: 163), thus also defining African-American women as "less female, and less human" (Jha 2016: 33). Because hair in addition to skin colour has been "historically devalued as the most visible stigmata of blackness" (Mercer qtd. in Tate 2008: 48), what is at stake in the eulogization of long, flowing and preferably blonde hair has to do with a simultaneous reinforcement of the constructs of gender and race. The coiled or nappy hair is both very dry (unless oiled it breaks easily all the time) and slow to grow, but if straightened it will grow much faster (Robinson-Moore 2008: 363). Long and flowing hair unlike short hair in the Western beauty paradigm is also a feminine attribute: silky and light to the touch (LaVon Walther 1990: 780), it suggests softness and yieldiness on the part of its wearer, rather than harshness, sturdiness and resistance, characteristics associated with masculinity. Thus the idealization of "straight flowing locks of whiteness" (Tate 2008: 19) carries the inscription of both feminine and racialized beauty standards that are structurally intertwined and doubly disempowering for African-American women and girls. These are the norms that prescribe impossible standards of beauty or "physical reductionism" for women (Pinder 2015: 119), against which a feminine subject, immersed into a racialized and patriarchal environment, is continually called upon to "measure, judge, discipline and correct itself' (Bordo 1993: 25).

This is also the fate of all female characters in the novel. The complex workings of this ideology and the way it also artificially divides and hierarchisizes women is best captured in the section where a light-skinned African-American girl of mixed descent with "sloe green eyes" and "with long brown hair braided into two lynch ropes [hanging] down her back" (Morrison 1994: 62) - denigrates other African-American girls for not coming anywhere near the patriarchally and white-defined feminine ideal:

We passed the Dreamland Theater, and Betty Grable smiled down at us. "Don't you just love her?" Maureen asked. "Uh-huh," said Pecola. I differed. "Hedy Lamarr is better." Maureen agreed. "Ooooo yes. My mother told me that a girl named Audrey, she went to the beauty parlor where we lived before, and asked the lady to fix her hair like Hedy Lamarr's, and the lady said, 'Yeah, when you grow some hair like Hedy Lamarr's.' " She laughed long and sweet. (1994: 69-70) 
As a light-skinned girl or what Morrison calls "a high-yellow dream child" with the hair type and length closer to the "destilled" markers of whiteness, Maureen Peal believes herself to be better and higher ranking than the rest of African-American girls in her classroom. Here Morrison subtly draws attention to the way both the structure and the length of the hair permeate every day discourse, featuring as one of the defining although in fact arbitrarily selected markers of one's closeness to "whiteness", and therefore also to desired femininity. This in turn translates into an acquired sense of either worthiness or worthlessness among the girls with the internalized white patriarchal male gaze now defining the way girls come to relate to each other. The result is the so-called internalized racism that breeds intra-racial prejudice, wreaking havoc on mutual love and respect among members within the community. Racialized beauty myth drives a wedge between members of the structurally marginalized community, eroding their solidarity and thus weakening their position even further. In this sense, it serves as an ultimate means of social control.

Reduced to spectral presence and entrapped by patriarchal white gaze, women, as Morrison demonstrates, learn to self-depreciate and to categorize and evaluate other women and girls in terms of their proximity to or distance from the imposed ideal of white patriarchal beauty paradigm. Significantly, Morrison removes men from the scene to show that this paradigm is structurally embedded and institutionally maintained rather than dependent on racial and sexist prejudice emanating from individual men, as liberal feminism would have it. Even though men are nowhere in sight, the patriarchal white gaze is not gone. Embedded into a broader social framework, it hovers in the background and it is all-pervasive. This controlling gaze stares down at African-American and white women alike from every billboard and school primer, regulating their perception of their own sense of self-worth which they also learn to accord to each other. The white patriarchal gaze regulates relationships between white and racialized women, creating an artificial divide between them too. Although African-American women are called upon to emulate white female icons of beauty, Claudia understands it is not white women that are the enemy. With both white and African-American women reduced to spectral presence, the controlling gaze is not that of an idealized white woman, against whom black women are called upon to compare and measure themselves. The female icons of white and feminine beauty are only conduits for the patriarchal white gaze, which in fact also determines the way these icons themselves continue to be positioned and circumscribed as feminine other. This is a crucial insight the main narrator of The Bluest Eye has to offer to the readership. Claudia observes: "And all the time we knew that Maureen Peal was not the enemy" (1994: 74) nor were the Shirley Temples and Mary Janes or for that matter African-American black girls whose eyes, in the presence of lighter-skinned and possibly sloe green-eyed African-American girls like Maureen Peal, would always "genuflect[] under sliding lids" (1994: 62). Maureen Peals of this world are not the enemy and "not worthy of intense hatred". Instead, "[t]he thing to fear was 
the Thing that made her beautiful, and not us." (Morrison 1994: 74). The "Thing" is of course the racist (and gendered patriarchal) ideology and its mechanisms of othering and dehumanization, which are a building block of exploitative social relations. It is this seemingly impalpable and indecipherable but in reality a very concrete and institutionally maintained ideology with its mechanisms of othering that is the real enemy.

Claudia as the informed narrator is the only one who resists the Western standards of white patriarchal beauty paradigm and it is through her informed point of view that the novel also strikes back at the root of racialized beauty myth, smashing it to smithereens. After first demonstrating the perfidious workings of the racialized and gendered beauty myth and the psychological damage left in its wake, the novel leads us to the central epiphanic moment when through Claudia we come face to face with the Thing itself. This is the moment of the exposure and the undoing of the ideology itself. When Claudia refers to her desire to "dis-member" white dolls in order to see and understand what they are made of, she symbolically talks of her desire to deconstruct and challenge the racist ideology. The idea is to strike at the heart of it: this means dismantling it piece by piece, revealing in the process its ungroundedness. By taking it apart, Claudia reveals that constructs of racialized beauty and otherness run on thin air, that behind racialized beauty myth and constructs of otherness there is no substance or truth. To deconstruct the racialized beauty myth is to demystify it, which is why Claudia must take the white dolls of this world apart:

I had only one desire: to dismember it. To see of what it was made, to discover the dearness, to find the beauty, the desirability that had escaped me, but apparently only me. Adults, older girls, shops, magazines, newspapers, window signs-all the world had agreed that a blue-eyed, yellow-haired, pink-skinned doll was what every girl child treasured. [...] I could not love it. But I could examine it to see what it was that all the world said was lovable. Break off the tiny fingers, [...] Remove the cold and stupid eyeball, it would bleat still, "Ahhhhhh," take off the head, shake out the sawdust, crack the back against the brass bed rail, it would bleat still. The gauze back would split, and I could see the disk with six holes, the secret of the sound. A mere metal roundness.

By dismantling the doll and deconstructing the racist ideology, Claudia can finally also get at the heart of social structures that maintain her secondary status. To see what this ideology is made of is to expose its hollowness and insubstantiality, which is also a way of imploding it. To trace the workings of the racist ideology and to dismantle it in the process of doing so results in a form of empowerment. Only by dismantling it can one also rise against this ideology and claim a different self, a self no longer shackled by the imposed constraints of gendered and racialized otherness. The task of the avant-garde eye/I is therefore not only to see through but also beyond these mechanisms of othering 
precisely by helping to undo them. This is also a message well grasped by students who at this point come to understand that whiteness is in fact a political category.

STUDENT A: Claudia as the narrator shows us how the beauty myth is imposed, how whiteness is glorified and blackness sneered at. ... Her anger, frustration and hopelessness also makes the reader see these constructs as artificial designs and makes them see racism for what it really is - a bogus ideological apparatus that wants to create a hierarchy based on non-existing differences and myths.

STUDENT E: Claudia refuses to conform to the racialized and gendered constructs of beauty, even though she understands they exist. With her dismembering of the dolls, she symbolically tries to unmask the white notion of beauty and discover how it operates. By doing so, she also disallows this ideology to influence her in a profound way.

STUDENT F: Claudia hasn't internalized the white gaze's aesthetic standards and is free to examine them critically. The excerpt encourages a shift in perception. The reader has to change their perception form the "default versus the Other" so that they can deconstruct their vision of whiteness as the invisible default to which everything else is contrasted. The approach to dealing with racism shouldn't be colourblindness but rather seeing colour ...

STUDENT G: She does not take cuteness at face value ... she wants to know what makes the white doll desirable. Through this, she questions the constructs of whiteness as the centre against which beauty is evaluated. Thus she removes "the cloak of invisibility draped over" whiteness as a central category and examines it critically. This invites the reader to do the same ... By "dismembering" whiteness we are able to see how it is constructed and to recognize why this is done."

\section{CONCLUSION}

The Bluest Eye implodes the racialized beauty myth by exposing the gendered and racialized constructs it is based upon and which it helps to perpetuate and naturalize. The Bluest Eye provides its readership with an in-depth understanding of the workings and the trappings of racialized beauty norms and offers a durable critical awareness, which in turn can help one to recognize and address the ways in which racialized beauty myth, and along with it white supremacy, continues to be naturalized today. Today, coercive beauty practices are 
"formed and reproduced in a political context of globalization, colonialism, and capitalism" (Jha 2016: 1). West-based beauty and fashion multi-million industries, music and filmindustries are all part and parcel of commodity capitalism. They have a direct stake not only in the commodification and sexualisation of women worldwide but also in the exportation and imposition of "a global Eurocentric beauty aesthetics" (2016:1) to the parts of the world newly annexed or re-annexed to the Western imperial interests. The imposition of the globalized and racialized ideal of femininity "continues to be defined primarily by lighter skin colour and Anglo-looking faces, bodies and straight and blond hair" (2016: $5)$. In its shaping of the globalized racial ideals of femininity, this industry propagates and homogenizes the image of the West as the seat of modernity and progress. Corporations like Nivea and Unilever have sought to increase their marketing share by selling whitening or bleaching creams to women in Asia, Latin America and Africa. In their marketing campaigns, they link the use of skin-lightening creams to professional success and upward mobility supposedly enjoyed by all Western women and which other women can achieve by making their skin more "beautiful" (2016: 53). Similarly, in addition to liposuction and breast implants, cosmetic industry promotes Eurocentric standards of beauty on a global scale. The most frequent procedures include "eyelid surgeries [among Asian and Asian American women] that add a crease to their eyelids to give them a more rounded appearance - more Western", and among women of African and Hispanic descent the most common surgeries are those "that make their noses longer or narrower - more Anglo" (Hunter 2005: 56). And last but not least, the institutionalization of Eurocentric beauty norms today takes place under the veneer of multicultural inclusion and promotion of diversity. What is at stake in this discourse is a token inclusion and an illusion of diversity that continues to revolve around the construction of whiteness as a seemingly neutral but in fact the defining centre and everything else as a cultural deviation. To be included into the hall of what is touted as hybridized or multicultural beauty, its icons must emulate whiteness. This goes true for Disney princesses like Jasmine and Pocahontas and for ethnicized Barbie dolls. Except for their difference in the dye of their plastic or celluloid skin colour, they are all carbon copies of "the same mythically thin, long-legged, luxuriously haired, buxom beauty" originally encapsulated in the "prototypical white Barbie" (Ducille 1994: 50). And this emulation of whiteness (or Caucasian features as the designers of Pocahontas themselves emphasize) under the façade of cultural diversity goes true for real people in the music and film industry, who in turn act as powerful idols for generations of teenagers and adults alike worldwide. In this sense, African-American pop icons like Beyoncé groom their appearance by making it look closer to the distilled features of whiteness: her "lighter skin and blond (dyed) hair reinforce whiteness" for her audience and for herself "as a site of [acceptable] femininity and beauty" (Jha 2016: 47). The Bluest Eye thus remains a contemporary piece of political writing: it has the power to make us aware of contemporary forms of racialized beauty constructs and the need to extricate ourselves from their grip by taking our own turn in dismantling and imploding them altogether. 


\section{LITERATURE:}

AZOUZ, Samy (2008) Cinema and Ideology in The Bluest Eye by Toni Morrison. AMERICANA: E-Journal of American Studies in Hungary, 4(2), Internet: http:// americanaejournal.hu/vol4no2/azouz

BAILLIE, Justine (2003) Contesting Ideologies: Deconstructing Racism in AfricanAmerican Fiction. Women: a cultural review 14(1), 20-36.

BARTKY LEE, Sandra (2003) 'Foucault, femininity, and the Modernization of Patriarchal Power. Rose Weitz (ed.) The Politics of Women's Bodies. New York and Oxford: Oxford UP, 25-45.

BARTHY LEE, Sandra (2002) Suffering to be beautiful. S. L. Bartky (ed.) "Sympathy and Solidarity" and Other Essays. Lanham, Boulder, New York and Oxford: Rowman and Littlefield Publishers, 13-30.

BERGER, John. (1998) Ways of Seeing. Lucinda Joy Peach (ed.) Women in culture: A Women's Studies Anthology. Malone, Oxford and Carlton: Blackwell Publishers Inc. $97-105$.

BORDO, Susan (1989) The Body and The Reproduction of Femininity: A Feminist Appropriation of Foucault. A. M. Jaggar/S. Bordo (eds.) Gender/Body/Knowledge: Feminist reconstructions of Being and Knowing, New Brunswick and London: Rutgers University Press, 12-33.

BORDO, Susan (1993) Unbearable Weight: Feminism, Western Culture and the Body. Berkley: University of California Press.

BURCAR, Lilijana (2017) Social Ills of (Global) Capitalism under Scrutiny in American Literature Classes: "Teaching to Transgress". Elope: English Language Overseas Perspectives and Inquires, 14(1), 25-38.

CAMP, Stephane H. M. (2015) Black is Beautiful: an American History. The Journal of Southern History, LXXXI (3), 675-690.

DAVIS, Kathy (2003) Beauty (the feminine beauty system). L. Code (ed.) Encyclopaedia of Feminist Theories. New York: Routledge, 54.

DUCILLE, Ann (1994) Dyes and dolls: Multicultural Barbie and the Merchandising of Difference. differences, 6(1), 46-68.

HOOKS, Bell (1992) Black looks: race and representation. Boston: South End Press.

HUNTER, Margaret L. (2005) Race, gender and the Politics of Skin Tone. New York and London: Routledge.

JHA, Meeta (2016) The Global Beauty Industry: Colorism, Racism, and the National Body. New York and Abingdon: Routledge.

LAVON Walther, Malin (1990) Out of Sight: Toni Morrison's Revision of Beauty. Black American Literature Forum, 24(4), 775-789.

LEEDS CRAIG, Maxine (2006) Race, beauty, and the tangled knot of a guilty pleasure. Feminist Theory, 7(2), 159-177. 
LISTER, Ruth (1997) Citizenship: feminist perspectives. Houndmills: Macmillan Press. MCROBBIE, Angela (2009) The Aftermath of Feminism: Gender, Culture and Social Change. London, Thousand Oaks, New Delhi and Singapore: Sage Publications.

MOI, Toril (1986) Sexual/textual politics: feminist literary theory. London and New York: Methuen.

MORRISON, Toni (1994) The Bluest Eye. Harmondsworth: Penguin.

MUNAFO, Giovanna (1995) No Sign of Life? - Marble Blue Eyes and Lakefront Houses in The Bluest Eye. L. A. Jacobus and R. Barecca (eds.) Literature Interpretation Theory. Toni Morriosn Issue. Langhorne, PA: Gordon and Breach Publishers, 1-20. MURNEN, SK/R. SEABROK (2012) Feminist Perspectives on Body Image and Physical Appearance. T. F. Cash (ed.) Encyclopaedia of Body Image and Human Appearance, Volume 1, London and San Diego: Academic Press (Elsevier), 438-443.

ORTNER, B. Shelly (1972) Is Female to Male as Nature is To Culture? Feminist Studies, 1(2) 5-31.

PINDER, Sharrow O. (2015) Colorblindness, Post-raciality, and Whiteness in the United States. New York and Houndmills: Palgrave MacMillan.

ROBINSON-MOORE, Cynthia (2008) Beauty Standards Reflect Eurocentric Paradigms - So What? Skin Color, Identity, and Black Female Beauty. The Journal of Race \& Policy, 4(1), 66-85.

TATE, Shirley Anne (2008) Black Beauty: Aesthetics, Stylization, Politics. Farnham and Burlington: Ashgate.

TAYLOR, Judith/Josée JOHNSTON/Krista WHITEHEAD (2016) A Corporation in Feminist Clothing? Young Women Discuss the Dove 'Real Beauty' Campaign. Critical Sociology, 42(1), 123-144.

TAYLOR, Paul C. (2000) Malcolm's Conk and Danto's Colors; or, Four Logical Petitions Concerning Race, Beauty and Aesthetics. W. Napier (ed.) African American Literary Theory: A Reader. New York and London: New York University Press, 665-672.

WILSON, Carter A. (1996) Racism: From Slavery to Advanced Capitalism. Thousand Oaks, New York and New Delhi: Sage Publications.

WOLF, Naomi (1992) The Beauty Myth: How Images of Women Are Used Against Women. New York: Anchor Books Doubleday.

\section{ACKNOWLEDGEMENT}

The author acknowledges the financial support of the Slovenian Research Agency (research core funding No. P6-0265). 


\title{
POVZETEK
}

\section{Razgradnja rasnega in patriarhalnega mita lepote skozi kritični pogled romana Toni Morri- son Najbolj modre oči (The Bluest Eye)"}

Prispevek razkriva in razčlenjuje ideološke podmene rasističnega mita lepote, kot jih raziskuje Toni Morrison v svojem romanu The Bluest Eye (Najbolj modre oči), pri čemer medsebojno strukturno preplete feministično teorijo in postkolonialno teorijo. Izpostavlja, da evrocentrične in torej rasistično zastavljene norme lepote temeljijo tako na konstruktih spola kot rase, in da služijo kot oblika družbenega pozicioniranja in družbene kontrole $\mathrm{v}$ zahodnih kapitalističnih patriarhalnih družbah. Tovrstno kontekstualno umeščeno razumevanje mita lepote, ki ga vzpodbuja tudi roman, je ključnega pomena tudi za razumevanje načina, na katerega mit lepote deluje danes v kontekstu globalne zahodnoevropske lepotne industrije. Osnovne podmene tega mita ostajajo globoko vpete $\mathrm{v}$ procese konstruiranja in vpisovanja družbenospolne in rasne drugosti, zavoljo česar roman ohranja trajno vrednost v svoji ozaveščevalni vlogi tako med bralstvom na splošno, in še prav posebej, kot dokazuje prispevek, med mladimi generacijami študentk in študentov angleške literature.

Ključne besede: mit lepote, lasje, rasni konstrukti, spolni konstrukti, družbena kontrola, kritična zavest, feministična teorija, The Bluest Eye, Toni Morrison

\begin{abstract}
This contribution investigates and lays bare the ideological workings of racialized beauty myth as presented in Toni Morrison's The Bluest Eye by bringing together feminist theory and postcolonial theory of race. It demonstrates that racialized beauty norms are informed by both the constructs of gender and race, and that they serve as a tool of social positioning and social control in Western capitalist patriarchies. This kind of contextual understanding, which Morrison's The Bluest Eye helps to foster on a number of structurally interlocked levels, is also of crucial importance for the understanding of the way beauty myth operates today in the context of globally exported Western beauty industry. Its basic tenets remain firmly rooted in the construction and perpetuation of racialized and gendered otherness, which is why The Bluest Eye remains an eye-opener and therefore a novel of lasting value for readers in general and, as this contribution demonstrates, for students of English literature in particular.
\end{abstract}

Key words: beauty myth, hair, racialized constructs, gendered constructs, social control, critical awareness, feminist theory, The Bluest Eye, Toni Morrison 